\title{
Interactions between perceived uncertainty types in service dyads
}

\author{
Kreye, Melanie
}

Published in:

Industrial Marketing Management

Link to article, DOI:

10.1016/j.indmarman.2018.04.014

Publication date:

2018

Document Version

Peer reviewed version

Link back to DTU Orbit

Citation $(A P A)$ :

Kreye, M. (2018). Interactions between perceived uncertainty types in service dyads. Industrial Marketing Management, 75, 90-99. https://doi.org/10.1016/j.indmarman.2018.04.014

\section{General rights}

Copyright and moral rights for the publications made accessible in the public portal are retained by the authors and/or other copyright owners and it is a condition of accessing publications that users recognise and abide by the legal requirements associated with these rights.

- Users may download and print one copy of any publication from the public portal for the purpose of private study or research.

- You may not further distribute the material or use it for any profit-making activity or commercial gain

- You may freely distribute the URL identifying the publication in the public portal

If you believe that this document breaches copyright please contact us providing details, and we will remove access to the work immediately and investigate your claim 


\title{
Interactions between perceived uncertainty types in service dyads
}

\author{
Melanie E. Kreye* \\ Department of Management Engineering, Technical University of Denmark, Denmark
}

\section{A R T I C L E I N F O}

\section{Keywords:}

Uncertainty

Servitization

Case study

\begin{abstract}
A B S T R A C T
This paper investigates the dynamic interactions between uncertainty types in service dyads between servitized manufacturers and their customers. This is an important research area because servitized manufacturers face multi-source uncertainty and need to manage this uncertainty effectively to avoid business failure. A conceptual framework of four uncertainty types is investigated: environmental, technological, organisational, and relational uncertainty. We present insights from four empirical cases of service dyads collected via multiple sources of evidence including 54 semi-structured interviews, observations, and secondary data. The cases show seven interaction paths with direct knock-on effects between two uncertainty types and indirect knock-on effects between three or four uncertainty types. The findings suggest a causal chain from environmental, technological, organisational, to relational uncertainty. This research contributes to the servitization literature by (i) confirming the existence of uncertainty types, (ii) providing an in-depth characterisation of technological uncertainty, and (iii) showing the interaction paths between four uncertainty types in the form of a causal chain.
\end{abstract}

\section{Introduction}

Servitization, where traditional manufacturing firms add services to their offerings (Vandermerwe \& Rada, 1988), has received much research attention in recent years (Kowalkowski, Windahl, Kindström, \& Gebauer, 2015; Richey, Musgrove, Gillison, \& Gabler, 2014). Specifically the difficulties of implementing such a strategy have been a major focus area in the literature (Kuijken, Gemser, \& Wijnberg, 2017; Luoto, Brax, \& Kohtamäki, 2017) because services are co-created with customers and obtain their value in use (rather than in production) (Vargo \& Lusch, 2004). Thus, challenges arise within the service dyad (Kreye, Roehrich, \& Lewis, 2015) and uncertainty has been highlighted as a core challenge (Nullmeier, Wynstra, \& van Raaij, 2016; Ulaga \& Kohli, 2018). Servitized manufacturers often assume responsibility for parts of the customer's processes (Nordin, Kindström, Kowalkowski, \& Rehme, 2011). As a result, providers are exposed to uncertainty that was previously assumed by customers (Nordin et al., 2011) including logistics within the customer's production (Sanchez Rodrigues, Potter, \& Naim, 2010) and the customer's demand structures (van der Vorst \& Beulens, 2002). This uncertainty is multi-source which means that servitized manufacturers need to simultaneously manage different uncertainty types (Simangunsong, Hendry, \& Stevenson, 2016; Yang \& Gabrielsson, 2017). Added challenges arise from potential interactions between these uncertainty types, increasing the potential for unknown and unanticipated knock-on effects with potentially disastrous outcomes. Thus, the ability to manage multi-source uncertainty and the potential interactions between uncertainty types is crucial for organisations, especially for servitized manufacturers (Kowalkowski, Gebauer, Kamp, \& Parry, 2017; Zhang \& Banerji, 2017).

The literature has offered different typologies of uncertainty types (Kreye, 2017a; Ulaga \& Kohli, 2018; Yang \& Gabrielsson, 2017) with the most influential and most widely recognised approach being the differentiation based on sources in relation to the organisation, differentiating external, internal, and relational sources (Simangunsong et al., 2016). External sources cause environmental uncertainty which is defined as the unpredictability of a company's external environment (Milliken, 1987). Internal sources - termed as organisational uncertainty - come from inside the focal organisation (Ulaga \& Kohli, 2018) and are connected to the potential lack of capabilities for conducting (part of) the operations. Organisational uncertainty is a core challenge in servitization and a main cause for business failure (Valtakoski, 2017) because of the variety of organisational capabilities needed for service provision (Galbraith, 2002; Ulaga \& Kohli, 2018). Relational uncertainty focuses on the predictability of partners' activities and can create large difficulties in the context of servitization (Kreye, 2017b). Additional challenges can arise from technological sources such as technology obsolescence (Pince, Frenk, \& Dekker, 2015). This can be captured in technological uncertainty (Melander \& Lakemond, 2015). While the literature offers in-depth insights into the specific nature of these uncertainty types in servitization (Kreye, Newnes, \& Goh, 2014; Melander \& Lakemond, 2015; Nullmeier et al., 2016), limited insights exist on interactions between these four

\footnotetext{
* Corresponding author at: Produktionstorvet 424, 2800 Kgs. Lyngby, Denmark.

E-mail address: mkreye@dtu.dk.
} 
Table 1

Conceptual framing of uncertainty types.

\begin{tabular}{|c|c|c|}
\hline Uncertainty type & Description & Perception in engineering services \\
\hline $\begin{array}{r}\text { Environmental } \\
\text { uncertainty }\end{array}$ & unpredictability of the external environment (Milliken, 1987) & $\begin{array}{l}\text { Potential market fluctuations in terms availability of supplies including finances } \\
\text { and material (Hypko et al., 2010) } \\
\text { Variation in customer demand in terms of timing and amount (Sampson \& } \\
\text { Spring, 2012) }\end{array}$ \\
\hline $\begin{array}{l}\text { Technological } \\
\text { uncertainty }\end{array}$ & $\begin{array}{l}\text { potential change in available technology over the life time of the } \\
\text { serviced product (van der Vorst \& Beulens, 2002) }\end{array}$ & $\begin{array}{l}\text { Obsolescence of technology during the service period making it difficult to } \\
\text { replace product parts during maintenance visits (Pince et al., 2015) } \\
\text { use unproven technology with respect to operation and maintenance activities } \\
\text { (Reim et al., 2016) } \\
\text { interaction of new technologies with existing product features (Melander \& } \\
\text { Lakemond, 2015). }\end{array}$ \\
\hline $\begin{array}{r}\text { Organisational } \\
\text { uncertainty }\end{array}$ & $\begin{array}{l}\text { Gaps in internal capabilities of the focal organisation (Galbraith, } \\
\text { 1974) }\end{array}$ & $\begin{array}{l}\text { Increased need for communication and information processing internally in } \\
\text { provider and customer organisations to have service-relevant information } \\
\text { available (Galbraith, 2002) } \\
\text { Staff skill-set in terms of service competencies (Baines et al., 2013) }\end{array}$ \\
\hline Relational uncertainty & $\begin{array}{l}\text { "inability to predict and explain the actions of a partnering organisation } \\
\text { due to a lack of knowledge about their abilities and intentions" (Kreye, } \\
\text { 2017b) }\end{array}$ & $\begin{array}{l}\text { Build close personal relationships between provider and customer staff (Kreye } \\
\text { et al., 2015) } \\
\text { Jointly solve conflicts and problems through professional interaction (Yang } \\
\text { et al., 2017) } \\
\text { Potential lack of inter-organisational trust between provider and customer } \\
\text { (Ulaga \& Eggert, 2006) }\end{array}$ \\
\hline
\end{tabular}

uncertainty types.

This paper investigates the following research question: how do uncertainty types interact in service dyads between servitized manufacturers and their customers? Presenting insights from four cases, the findings show seven distinct interaction paths with direct and indirect knock-on effects between two, three, or four of the investigated uncertainty types. The findings suggest that there is a causal chain of interaction from environmental uncertainty, technological uncertainty, organisational uncertainty, to relational uncertainty. This research contributes to the servitization literature in three ways. We offer confirmatory evidence for the existence of different uncertainty types in service dyads. We further contribute a detailed characterisation of technological uncertainty in servitization which has not been described before in this context. Finally, we show distinct interaction paths between four uncertainty types in the form of a causal chain.

\section{Literature review}

Servitization is defined as the process whereby a traditionally product-focused company integrates services into their business models (Kowalkowski et al., 2017). The aim is to improve customer loyalty and lock-in situations by selling highly innovative technologies and associated services (Kastalli \& Van Looy, 2013). Specifically, engineering services are an important focus because they build on the existing technological competencies of manufacturing firms (Zink, Baudach, \& Kramp, 2010). Operational challenges arise from the typical production tradition of many manufacturers with limited attention on the customer-centric support of their products through life (Zhang \& Banerji, 2017). Engineering services are operationally highly complex (Forkmann, Ramos, Henneberg, \& Naudé, 2017) and require different managerial approaches to activities including organisation structure and human resource management (Baines, Lightfoot, Smart, \& Fletcher, 2013; Zhang \& Banerji, 2017), performance assessment (Melander \& Lakemond, 2015), financial flow management (Hypko, Tilebein, \& Gleich, 2010), and provider network management (Eloranta \& Turunen, 2016). Furthermore, services are inherently dynamic due to their "open" nature and require constant adaptation to customer requirements and business context such as industry standards (Hakanen, Helander, \& Valkokari, 2017). Because of these differences between traditional manufacturing and engineering services, uncertainty is a key challenge for servitized manufacturers (Kreye et al., 2014; Melander \& Lakemond, 2015; Nullmeier et al., 2016; Ulaga \& Kohli, 2018).

\subsection{Uncertainty in servitization}

Uncertainty can be defined as the lack of understanding which arises from not definite, not known or not reliable information (Kreye, Goh, Newnes, \& Goodwin, 2012). Uncertainty captures the lack of understanding (Kreye et al., 2012) and differs from risk which is defined as the possible effect of an uncertain event or situation (Lewis, 2003). This research focuses on uncertainty because of the importance to servitization and the provision of engineering services (Hypko et al., 2010; Kreye, 2017a; Zhang \& Banerji, 2017). Uncertainty creates challenges for managing the service dyad in terms of contractual (Melander \& Lakemond, 2015), relational (Kumar \& Yakhlef, 2016), and operational management (Luotola, Hellström, Gustafsson, \& Perminova-Harikoski, 2017). We do thus not discuss risk further. Specifically, we focus our attention to uncertainty in engineering services because of importance of uncertainty in this context (Zhang \& Banerji, 2017) and the potential dynamic nature of uncertainty throughout service provision (Selviaridis, 2016) suggesting a suitable focus area for the purpose of this research.

The literature has offered different typologies of uncertainty based on different criteria and developed within different empirical and theoretical areas. Examples here are Simangunsong et al. (2016) who describe external, internal, and relational sources of uncertainty, Ulaga and Kohli's (2018) description of needs, process and outcome uncertainty in services, or Yang and Gabrielsson's (2017) differentiation of internal, technological, and market uncertainty. Specifically, typologies based on the source of the uncertainty have received much attention in the literature and proven to be a theoretically sound approach within the context of management and services specifically (Kreye, 2017b; Milliken, 1987; Simangunsong et al., 2016; Yang \& Gabrielsson, 2017). We thus utilise this approach and differentiate four uncertainty types based on their specific sources as follows: environmental, technological, organisational, and relational uncertainty. Table 1 offers a summary of the different uncertainty types which we use as the conceptual basis for our investigations.

Environmental uncertainty reflects the unpredictability of the external environment (Milliken, 1987) due to, for example, market fluctuations (Hypko et al., 2010), varying customer demand (Luotola et al., 2017) or competitor offerings (Kreye et al., 2014). Environmental uncertainty lies outside of the focal organisation's direct influence (Simangunsong et al., 2016). It may arise from foreseeable events such as variations in availability of supply (Chao, Chen, \& Zheng, 2009) or economic developments (Hypko et al., 2010). This has been particularly 
investigated for performance-based arrangements (Hypko et al., 2010), where environmental uncertainty may be connected to fluctuations in the availability of material, parts and tools in terms of quantity and/or timing of supply with negative effects on operational performance (Nullmeier et al., 2016). Environmental uncertainty can also arise from unforeseeable events such as political unrests (Hoskisson, Eden, Lau, \& Wright, 2000) or natural disasters (Pearson \& Clair, 1998). Here, the possible effects of environmental uncertainty can be as severe as operational disruptions to the servitized agreement (Kreye, 2017a).

Technological uncertainty is defined as the potential change in available technology over the life time of the serviced product (van der Vorst \& Beulens, 2002). It can relate to technology obsolescence where product parts may not be available for replacement (Pince et al., 2015). Other issues can arise from unproven technology (Reim, Parida, \& Sjödin, 2016) or the interaction of new technologies with existing product features (Melander \& Lakemond, 2015). Technological uncertainty has not been explored in depth within the context of servitization where insights regarding its nature and possible occurrence are still missing. This is a gap this paper aims to fill.

Organisational uncertainty arises from within an organisation (Galbraith, 2002) and captures the potential lack of capabilities. It has received attention within the servitization literature because of the high importance of internal challenges in this context (Luoto et al., 2017; Zhang \& Banerji, 2017). It can arise from the operational differences between service and production (Eloranta \& Turunen, 2016) with increased needs of information processing (Galbraith, 2002). Services challenge the provider because of their inability to control quality levels (Hawkins, Gravier, Berkowitz, \& Muir, 2015) and the need for operational flexibility and heterogeneity (Kastalli \& Van Looy, 2013). Organisational uncertainty has been described with regard to uncertain maintenance costs (Hypko et al., 2010), increased execution challenges (Kuijken et al., 2017), and the provider's potential inability to process information internally which can affect their ability to provide the engineering service (Kreye, 2017b).

Relational uncertainty is the inability to predict or explain a partner's actions (Kreye, 2017b). It exists because of the central importance of close relationships in servitization which may result in unintended customer behaviour (Hakanen et al., 2017; Kuijken et al., 2017). It can arise from the dependence on the customer's diligence, commitment and responsibility (Nullmeier et al., 2016), and the customer's changing needs (Hawkins et al., 2015). The need for close customer relationships also increases the likelihoods of conflicts, disagreements and opportunistic behaviour (Yang, Gao, Li, Shen, \& Zheng, 2017). In contrast, close customer relationships may also align goals between provider and customer and result in closer ties (Ulaga \& Kohli, 2017). Thus, relational uncertainty is a core uncertainty type in the provision of engineering services.

\subsection{Interaction between uncertainty types}

Research has hinted on possible interactions between uncertainty types in servitization. However, no structured analysis of interactions between uncertainty types exists. Offering such an analysis however is important because it enables servitized manufacturers to focus their uncertainty management activities and target the root cause of a perceived uncertainty type (Simangunsong et al., 2016). Interactions between uncertainty types can pose significant management challenges especially when management activities are targeted at coping with uncertainty but need to be targeted at its root cause (Simangunsong et al., 2016).

Prior research investigating uncertainty types in servitization suggests a causal chain between them. In their study of servitized triads, Kreye (2017a) found that environmental uncertainty in the form of unforeseen events can cause organisational uncertainty in the form of operational disruptions and performance reductions. This in turn caused relational uncertainty between customer and provider in the form of disputes and conflicts. Similarly, Kreye (2017b) found a direct relationship between organisational uncertainty and relational uncertainty. They observed that the customer's (provider's) unresolved organisational uncertainty in the form of lacking capabilities to process information internally caused relational uncertainty for the provider (customer). These observations suggest a causal chain from environmental uncertainty to organisational uncertainty and relational uncertainty in servitization.

Other interactions between uncertainty types could also be possible based on the wider literature. For example, the experience of high levels of relational uncertainty with the customer can reduce the service provider's ability to explore the customer's external environment in terms of their competitors, market, and the customer's customers (van der Vorst \& Beulens, 2002). This means that fluctuations in the customer's environment could come unforeseen and unexpected, creating high levels of environmental uncertainty. Here high levels of relational uncertainty could increase levels of environmental uncertainty. Similarly, high levels of environmental uncertainty could create technological uncertainty where disruptions created by exogenous influences such as geopolitical or natural events create an incentive for the development of disruptive technologies (O'Connor \& Rice, 2013). Thus, there may be varying bi-directional interactions between uncertainty types contradicting the initial suggestions of a causal chain. This research utilises a conceptual framework of potential bi-directional interactions between uncertainty types to identify how uncertainty types affect each other in servitization and where root causes of uncertainty types lie.

\section{Method}

To answer the research question, a case-based approach was adopted for the following reasons. A lack of prior in-depth investigation into the topic and hence a lack of existing frameworks to formulate hypotheses gives need to exploratory research in this area (Eisenhardt, 1989). Case-based research offers the empirical evidence needed to improve understanding and build theory (Siggelkow, 2007). Further, case-based research enables the researcher to immerse themselves within the empirical context of their cases and thus offers the ability for in-depth investigations into the researched phenomenon (Yin, 2009). This is particularly important in servitization because additional factors such as the nature and size of service portfolio (Kastalli \& Van Looy, 2013) may affect observations. Furthermore, the multiple-case design enabled the researchers to investigate our research question in a situationally grounded way while seeking a sense of generalisability (Beverland \& Lindgreen, 2010). Thus, the multiple-case approach was suitable for the purpose of this research.

\subsection{Research design}

This paper presents insights from four case studies which consist of dyads between servitized manufacturer and their customer. This is a suitable research design because in servitization, systems compete rather than individual companies (van der Vorst \& Beulens, 2002). The case contexts were anonymised to protect the companies' identities. The cases were chosen based on theoretical criteria of servitized manufacturers offering service support for their products. The specific customer dyad was identified during discussions with the providers based on successful relationships and accessibility of both provider and customer for data collection. The cases were chosen based on theoretical criteria of the servitized offering enabling comparability between the presented dyads to enable triangulation and build theory (Piekkari, Plakoyiannaki, \& Welch, 2010; Yin, 2009). Furthermore, the cases were selected for their differences in contextual settings to enable analysis of a broad set of industrial sectors where PSS provision is relevant. This again supported triangulation of the insights and mitigated the influence of observer bias on the obtained findings (Beverland \& Lindgreen, 
2010).

The four cases were set in the UK electronics industry, the European water treatment industry, the European healthcare industry, and the Nordic renewable energy industry respectively. These industry sectors are relevant for this research because they have experienced strong pressures for companies to engage in servitization (Baines et al., 2013; Pereira \& Carvalho, 2011). Case A focused on the provision of equipment maintenance including inspections and repairing of faults and breakdowns for electrical control systems with the aim of minimising downtime. Provider A (PA) was a globally operating manufacturer producing actuators and other control systems and servicing these on customer sites. Customer A (CA), was a locally operating public organisation providing water treatment and cleaning services to local residents and companies. Case B focused on the provision of corrective and preventative maintenance services for water pumps. Provider B (PB) was a globally operating manufacturer of pumps and provider of after-sales care such as repairs and maintenance. Customer B (CB) was a private facilities management company operating on the premises of a government building. Case $\mathrm{C}$ focused on the provision of services including corrective and preventative maintenance and product upgrades. Provider C (PC) was an internationally operating manufacturer and service provider of diagnosis and treatment equipment including MRI scanners. Customer C (CC) was a publicly-run hospital providing healthcare services to private patients. Case D was set in the Nordic renewable energy sector. Provider D (PD) was a globally operating manufacturer of wind energy generation equipment including after sales services. Customer D (CD) was a locally operating energy provider to the national electricity grid.

\subsection{Data collection}

Each case study was collected utilising multiple sources of evidence. The researcher stayed at the case companies for multiple days to observe operations, engage in meetings and in-depth discussions, and collect interviews and secondary data including documentation notes from multiple site visits to the companies' head offices and customer sites, service contracts, annual reports, presentations, marketing material, and announcements on webpages and similar (Piekkari et al.,
2010, Yin, 2009). The specific numbers of interviews and interviewees for the four cases are listed in Table 2. The interviewees were selected based on their involvement with the specific case contract, their engagement with the collaboration partner and involvement with the service operations. The interviews varied in length between 30 and $90 \mathrm{~min}$, were recorded and transcribed. The data collection stopped when conceptual saturation was achieved (Yin, 2009).

The semi-structured interviews were guided by a questionnaire covering a set of issues regarding the PSS operations and the companies' relationship. The discussed topics included business strategy and the global and local business environment, the technology and technological developments, the nature of the service operations and organisation, and the inter-organisational relationships during the contract negotiations and after contract signature. The interviews did not specifically discuss uncertainty or the interviewees' uncertainty perception as this was found to bias interviewees in their discussions and thus reduce the usefulness of the gathered findings (de Bruin, Fischbeck, Stiber, \& Fischhoff, 2002, Kreye, Newnes, \& Goh, 2013). For example, de Bruin et al. (2002) found that the explicit discussion of uncertainty with interviewees leads them to resolve part of their perceived uncertainty which reduced the reported levels and detailed descriptions of uncertainty and hence distorted findings. Thus, this research tried to uncover the sources of this uncertainty through the discussions by focusing on the areas of the business environment, technology, organisation and relationship. Specific topics were followed-up on and clarified to provide further depth. The interviews were conducted one-to-one in employees' offices, designated meeting rooms, or in exceptional cases via telephone or video conference.

\subsection{Data analysis}

The unit of analysis is the service dyad between provider and customer. The data were carefully analysed in two main steps. First, a within-case analysis was conducted based on the interview transcripts and additional material using systematic combining (Dubois \& Gadde, 2002). The authors coded the data initially in thematic categories based on the conceptual framework following the research question and comprehensive literature review (Miles, Huberman, \& Saldaña, 2014).

Table 2

Data collection for six cases.

\begin{tabular}{|c|c|c|c|c|}
\hline & Case A & Case B & Case $\mathrm{C}$ & Case D \\
\hline Sector & UK electronics sector & European water treatment sector & European Healthcare sector & Nordic renewable energy sector \\
\hline $\begin{array}{l}\text { Provider (approximate employee and } \\
\text { revenue numbers from 2016) }\end{array}$ & $\begin{array}{l}\text { Manufacturer of control } \\
\text { systems such as actuators } \\
3500 \text { employees } \\
\text { Revenue: } 670 \mathrm{~m} €\end{array}$ & $\begin{array}{l}\text { Manufacturer of water treatment } \\
\text { pumps } \\
18,900 \text { employees worldwide } \\
\text { Revenue: } 3 \text { b€ }\end{array}$ & $\begin{array}{l}\text { Manufacturer of healthcare } \\
\text { diagnosis equipment } \\
45,000 \text { employees worldwide } \\
\text { Revenue: } 14.5 \text { b€ }\end{array}$ & $\begin{array}{l}\text { Manufacturer of wind energy } \\
\text { production equipment } \\
21,500 \text { employees } \\
\text { Revenue: } 8.4 \text { b€ }\end{array}$ \\
\hline Time spent on provider site & 1 day & 2 days & 2 days & 2 days \\
\hline Provider interviewees & $\begin{array}{l}\text { Service engineer } \\
\text { Sr Service engineer } \\
\text { Service manager } \\
\text { Sales manager } \\
\text { General manager }\end{array}$ & $\begin{array}{l}\text { Service engineer } 1 \\
\text { Service engineer } 2 \\
\text { Service engineer } 3 \\
\text { Administrator } 1 \\
\text { Service planner } \\
\text { Service coordinator } \\
\text { Office manager } \\
\text { Sales manager } 1 \\
\text { Sales manager } 2 \text { (semi-retired) } \\
\text { Accounts manager } \\
\text { Service manager } 1 \\
\text { General manager }\end{array}$ & $\begin{array}{l}\text { Service manager } \\
\text { Business controller } \\
\text { Invoice administrator } 1 \\
\text { Invoice administrator } 2 \\
\text { General manager } \\
\text { Sales manager } \\
\text { Account manager } \\
\text { Service engineer } 1 \\
\text { Service engineer } 2\end{array}$ & $\begin{array}{l}\text { Manager of Customer Service } \\
\text { Customer Service Manager } 1 \\
\text { Customer Service Manager } 2 \\
\text { Customer Service Manager } 3 \\
\text { Controlling Administration } \\
\text { Manager } \\
\text { Regional Manager } \\
\text { Site Manager } \\
\text { Quality Performance Expert } \\
\text { Senior Business Manager }\end{array}$ \\
\hline Customer & $\begin{array}{l}\text { Operator of water treatment } \\
\text { facilities }\end{array}$ & $\begin{array}{l}\text { Facilities management company for } \\
\text { national government building }\end{array}$ & Publicly-run hospital & $\begin{array}{l}\text { Provider of Electric energy from } \\
\text { renewable sources }\end{array}$ \\
\hline Time spent on customer site & 1 day & 1 day & 1 day & 1 day \\
\hline Customer interviewees & $\begin{array}{l}\text { Electrician } 1 \\
\text { Electrician } 2 \\
\text { Technical manager } 1 \\
\text { Technical manager } 2 \\
\text { Eng. Supervisor }\end{array}$ & $\begin{array}{l}\text { Mechanical engineer } \\
\text { Engineering Supervisor } \\
\text { Administrator } 2 \\
\text { Service manager } 2\end{array}$ & $\begin{array}{l}\text { Strategic buyer } \\
\text { Chief physicist } \\
\text { Physicist } 1 \\
\text { Physicist } 2 \\
\text { Physicist } 3\end{array}$ & $\begin{array}{l}\text { Service Operations Manager } \\
\text { Operations Manager } \\
\text { Procurement and Project } \\
\text { Manager } \\
\text { Managing Director }\end{array}$ \\
\hline
\end{tabular}


Subsequently, the data were coded based on the researchers' understanding and interpretation of the data. The thematic categories emerged based on the empirical data by combining empirical data analysis, collection and the literature to facilitate theory building (Miles et al., 2014). The coding structure was created and refined iteratively by identifying links between the investigated concepts (Miles et al., 2014) which allowed the researchers to create a cognitive map of the case events and identify links between local incidents in the case studies. Data was triangulated to mitigate bias and improve validity and case study rigour (Miles et al., 2014). Furthermore, each of the cases was written up as a case report and presented to the companies for verification and discussion to give an opportunity to comment on observations and initial conclusions. This allowed for further clarifications and refinements of the conclusions. Second, cross-case analysis was conducted (Eisenhardt \& Graebner, 2007) to identify common characteristics. For this, the authors connected and compared codes from the within-case analysis in an iterative process to obtain a detailed and in-depth empirical description of the interactions between uncertainty types. Increasingly a higher level of abstraction was achieved. This iterative approach gave a full picture of the presented cases with regard to the research focus.

\section{Findings}

\subsection{Overview of cases}

This section gives an overview of the cases and the uncertainty perceived by servitized manufacturers and customers. Table 3 summarises this overview for the four cases.

\subsubsection{Case A - Control systems}

In Case A, the PA's service portfolio focused on emergency repairs and "on site overhaul \& testing, health checks (for the technical equipment) \& Preventative maintenance, (...) and firmware upgrades" (Company presentation, PA). Service manager 2 (PA) explained: "The whole business is running mainly from service. Meaning equipment sales give some profit but long term profit is from service. After delivering the equipment we have ten year service and from service we win the money." The case contract was the first formally agreed framework contract with the customer. Beforehand, they engaged in ad-hoc arrangements where maintenance services were provided as and when needed.

The service partners faced various uncertainty types in the investigated arrangement. Technological uncertainty arose from the technological developments in the control systems which would change operations and maintenance processes. The Sales manager (PA) explained: "[We have] the old range of actuators, there's still thousands out there. And then the new range of infra-red actuators." The range of equipment offered by PA and the technological difference due to technological development created technological uncertainty in Case A. Organisational uncertainty arose from the nature of the service operations. For example, the Service manager (PA) explained: "we had to change the dynamics of how we work. [For instance, we had to] get more service vehicles in [to cover our internal demand]. "This differed from their product-focused business as the Service manager (PA) continued their description: "We do quite a lot of supply-only jobs, when we just supply them [a product] in a box and their engineers fit it. "Relational uncertainty was connected to difficulties of accessing the customer site as the General manager (PA) exemplified: "an engineer would go to do the work and he wouldn't get access." Furthermore, the provider received service requests that were not covered in the service agreement as the Service manager (PA) explained: "a lot of times, we get out there and all it was we had to change the battery, which is something they could or should be able to do." Case A observations hence included technological, organisational and relational uncertainty.

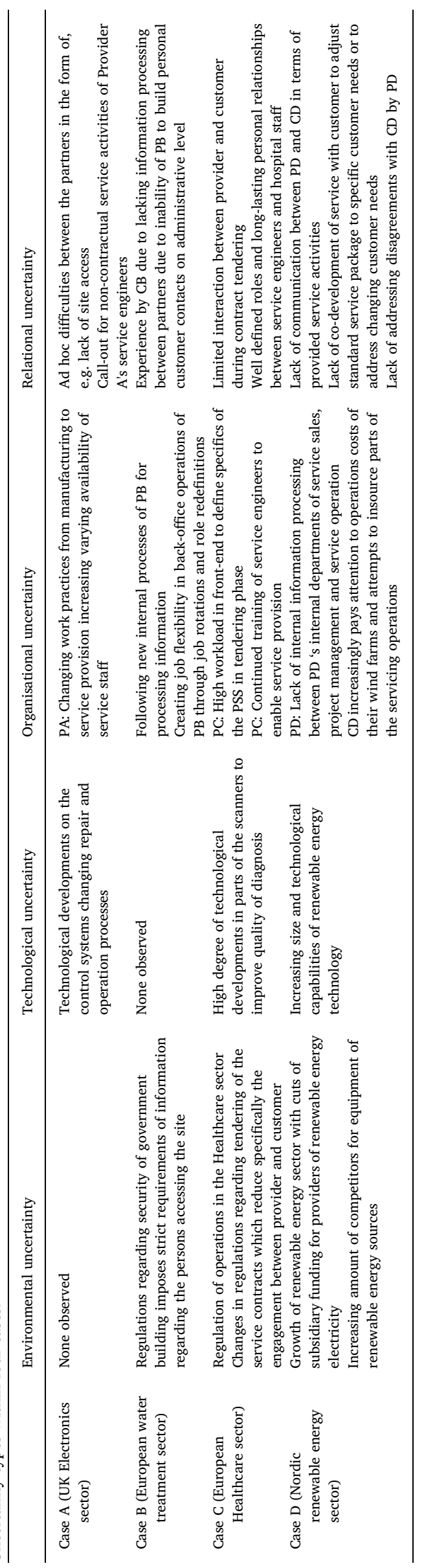




\subsubsection{Case $B$ - Water treatment}

For Provider B, services were a key part of their offerings as their General manager (PB) explained: "Service is now becoming a huge factor. This is a new area for growth and for increased revenue. So we are looking to expand on service." The case contract was the first formal agreement between provider and customer. Beforehand, they engaged on an ad-hoc basis as the Service manager 2 (PB) explained: "[the customer] just rung me up or he might ask for a bit of advice on the phone". This defined the interaction and nature of relationship in the service dyad in Case B.

The partners in Case B experienced different uncertainty types. Environmental uncertainty arose from the security regulations regarding site access to the customer site requiring information in terms of the identity of the service engineers wishing to access the building and their car registration as the Service manager (PB) explained: "the security is higher than normal. [This concerns access]. So it might be days that we might not be able to go." Organisational uncertainty arose for PB because they re-organised their back office and rotated staff between different roles to create task flexibility. As a result, the provider employees were uncertain in terms of their specific tasks and customerspecific processes. Administrator 1 (PB) described "Everyone was given redefined job roles to try and make things work a little better." This created temporary additional organisational uncertainty for PB. Relational uncertainty arose for the partners because of the lack of communication regarding service visits as the Engineering Supervisor described: "there were visits [in the early stages] where an engineer has turned up unannounced. (...) I had to send the guy away because nobody knew who he was." This lack of communication resulted in various situation where the customer was unhappy with the service they received.

\subsubsection{Case $C$ - Healthcare equipment}

Case C included a long-standing relationship where PC had been servicing different pieces of equipment for CC in previous decades. However, the focus on services had recently become more and more important where the customer had an increasing focus on operational performance. The Section head (CC) described: "we want higher uptime and we want a quick response time." PC had thus included services in their company strategy as Service manager 2 (PC) explained: "The whole business is running mainly from service. Meaning equipment sales give some profit but long term profit is from service. After delivering the equipment we have ten year service and from service we win the money."

Case C showed observations of the different uncertainty types. Environmental uncertainty arose from the change in regulations in the European healthcare sector regarding the operations and tendering for equipment and related services. The Sales manager (PC) explained: "The rules changed. We used to sell systems without tenders at that time." The aim of this change was to make the procurement more competitive within the European market and affected the procurement process. Technological uncertainty was connected to the high degree of technological developments in the healthcare equipment. The Service manager (PC) explained: “"In the old days, people where trained for a month on the scanner. (...) But now the [equipment is] more advanced. (...) More advanced equipment, more compact, more effective service and more concentrated training."

Organisational uncertainty existed mainly in the tendering process where the majority of the workload accumulated. The Physicist (CC) explained: "The workload tends to be quite substantive. You almost need to have a legal department nowadays to handle these things." Once contracts were signed, the organisational uncertainty was relatively low due to strict procedures based on tight regulations. Relational uncertainty was also relatively low because roles were clear and specialists worked with the customer departments on a longterm basis. The provider's relational capabilities relied heavily on the individual service engineer as explained by the Service manager (PC): "you are doing some more nursing at this site than the agreement there and that is due to the nature of [Service engineer 1] because he is very caring and he is the service specialist for that area." Thus, the relationships between provider and customer were well defined with low levels of relational uncertainty.

\subsubsection{Case D - Renewable energy}

Services had become a very important part of the offering in the Nordic renewable energy sector as the Key account manager (PD) explained: "Our motivation for providing services is like any other maturing industry. Prices and margins go down on the equipment and then you have to extend your business and there is no better way. Chapter $1 A$ is service." Case $\mathrm{D}$ consisted of a long-standing relationship, however, with limited involvement between PD and $\mathrm{CD}$ as their Controlling Administration Manager explained: "The customer has 'some' engagement. (...) they have quite a few parks." The wind parks were removed from the customer's offices which meant that limited direct interaction between provider and customer was required to do service activities.

Case D showed various instances of the different uncertainty types. Environmental uncertainty arose from the large growth of the renewable energy sector in Nordic countries and the cuts in government subsidies. The Managing director (CD) explained: "The prices were unhealthy, so that was the reason that we started for our services."Technological uncertainty was connected to the increasing size and technological capabilities of wind turbines on the market. The Service controlling administration manager (PD) described: "Our strategy was to move away from small turbines. We are leaving that more and more." Thus, the technological development on the market led PD to focus their service business on larger infrastructure.

Organisational uncertainty arose from the operational differences of services to manufacturing and was specifically connected to the lack of internal communications at PD. The Controlling administration manager explained: "There is a gap between service sales and service. (...) we are not a part of actually making the contract saying yes we can live up to this, but not to this." Furthermore, most contracts contain non-standard content which created difficulties for the service operation as the Site manager (PD) described: "But we need to know what to deliver. Knowing the promises that have been made." Furthermore, the customer paid increasing attention to operational costs and processes as the Customer Service Manager 1 (PD) explained: "They demand more data. They are on top of what is happening and are more engaged in their ownership. "Relational uncertainty arose from the lack of communication between provider and customer leading to a lack of agreeing an individualised service arrangement based on the customer's needs, lacking cooperation in regard to service operations, and a lack of addressing disagreements between provider and customer. The Manager Customer Service (PD) explained: "The thing that is missing is communication. Our customers are not aware of what we are doing and we don't tell them." Thus, all four uncertainty types were observe din Case D.

\subsection{Interaction between uncertainty types}

The case observations showed various interactions between the four uncertainty types. Environmental uncertainty created direct knock-on effects to the other three uncertainty types. Specifically, the effects on organisational and relational uncertainty depended on the specifics of regulation changes. Environmental uncertainty caused organisational uncertainty as observed, for example, in Case C. Here, the changes in regulations to the tendering process increased the workload for potential providers and the customer when preparing the tender in a competitive bid. The Account manager (PC) explained: "if you win, you win a lot. If you lose, you lose a lot." These regulations also specified the nature of interaction between provider and customer and thus the level of relational uncertainty. The Service manager (PC) explained: "We are all [all competitors] evaluated objectively. That means the relations are not there at all on the paper. But of course in the real world, there are some relations that are still working. But not as it used to be." Thus, environmental uncertainty directly affected organisational uncertainty and 
relational uncertainty.

Environmental uncertainty also created two-tier knock-on effects on organisational uncertainty and relational uncertainty in turn. For example, in Case B the policy change towards information requirements for people accessing the customer site affected the information the provider needed to communicate prior to service visits. The Engineering Supervisor (CB) described: "there were visits [in the early stages] where an engineer has turned up unannounced. (...) I had to send the guy away because nobody knew who he was." A similar example was observed in Case D where cuts in government subsidies in wind energy caused $\mathrm{CD}$ to become more concerned about operational costs which in turn meant that they were much more controlling of PD's activities. The Customer Service Manager 2 (PD) explained: "They [CD] are hiring people to be my counterpart to check up on the service. They demand more data. They are on top of what is happening and are more engaged in their ownership. Before they just wanted us to say when we were there. But now they want to know why we are doing things and what we are doing." This shows the indirect knock-on effects of environmental uncertainty on relational uncertainty.

Environmental uncertainty created also three-tier knock-on effects on organisational uncertainty via technological uncertainty. In Case D, the increase in competition for small wind turbines created a drive for technological developments of larger turbines which in turn created a re-focus of Provider D's strategy on servicing these large-scale turbines. The Key Account Manager (PD) described: "In Sales, if we had not adapted we would not have sold any turbines. In that sense, they [CD] get a readymade deal." Similarly, environmental uncertainty created four-tier knock-on effects on relational uncertainty via technological uncertainty and organisational uncertainty in turn. This was observed in Case C where changing needs of the customer base of PC gave incentives for technological developments which in turn led to operational specialisation of PC's service engineers. The Service Manager (PC) explained: "they all have to be trained continually and they need to be certified. That means they have to go through certain courses and keep the service certification." This in turn led to changes in managing the customer relationship because it was the specialised service engineer who build long-term personal links with customer personnel. Physicist 2 (CC) described: "If you have a problem, you would call a technician. He will be here within half hour or an hour."

Technological uncertainty was observed as the root cause for relational uncertainty via organisational uncertainty. This was observed, for example, in Case A where the technological developments in the equipment increased organisational difficulties for Customer A to operate the equipment and do first-line services in house. This resulted in increased service call-outs for unnecessary service activities which were not covered by the service agreement. The service manager (PA) described: "a lot of times, we get out there and all it was we had to change the battery, which is something they could or should be able to do." The customer was not able to develop the technological skills needed to operate and maintain new equipment in-house. This shows the indirect knockon effects from technological uncertainty to relational uncertainty.

Organisational uncertainty caused relational uncertainty. For example, in Case A CA's lacking capabilities to process information internally led to difficulties for PA with regard to arranging service visits to the customer site. The General manager (PA) described: "an engineer would go to do the work and he wouldn't get access." Similarly in Case B, PB's lacking capabilities to process information internally led to dissatisfactions of $\mathrm{CB}$ with regard to the service because relevant information was not provided to them. The Engineering supervisor (CB) explained: "[They - $P B$ - need to] work on their communication. Even if it's going to take a couple of days to put a quote together just a quick email [would be enough]." Another example was Case D where PD's internal misalignments and lack of internal communications led to disagreements with $\mathrm{CD}$. The Quality Performance Expert (CD) explained: "They [PD] are not used to such an active customer. They want to keep them within the contracts." Thus, unresolved organisational uncertainty of one partner caused relational uncertainty for the other partner in the presented cases.

\section{Discussion and conclusions}

This section discusses the findings of the four cases with regard to the research question, eliciting the theoretical contribution, managerial implications, limitations and future work.

\subsection{Theoretical contribution}

This research contributes to the servitization literature and more specifically to uncertainty management within operations by furthering theory building in the area of managing multi-source uncertainty. Specifically, we offer the following three distinct contributions. First, the provided insights confirm prior descriptions of uncertainty types in the servitization literature regarding the existence of environmental uncertainty, organisational uncertainty and relational uncertainty (Kreye, 2017a; Simangunsong et al., 2016). Second, this research added a fourth uncertainty type with respect to technological uncertainty providing a nuanced characterisation of this concept. This characterisation expands the literature which highlights technological obsolescence as a key factor in service provision (Pince et al., 2015). Third, and most importantly, this research provides insights on the interactions between these four uncertainty types suggesting a causal chain with direct or indirect effects between them.

This research confirms existing theory on the uncertainty types affecting operations in servitization. Specifically, the literature has described environmental uncertainty, organisational uncertainty and relational uncertainty in this context (Kreye, 2017a, Simangunsong et al., 2016). This research adds to these descriptions by giving a first empirically founded description of technological uncertainty in the context of servitization. This description is based on the concepts of technological developments and obsolescence which have been highlighted in their effect on the operations of servitized manufacturers (Pince et al., 2015). Our investigation of technological uncertainty provides a more nuanced characterisation as the case observations showed. External pressures for technological developments in terms of advancements and resulting increasing complexity create technological uncertainty for servitized manufacturers and their customers in terms of their operations as shown in, for example, Cases A and C. Here, the servitized manufacturer merely reacts to technological developments and adapts their capabilities accordingly. In contrast, technological developments can also be driven internally by the servitized manufacturer to increase or ensure their competitiveness as shown in Case D. Here, it is the servitized manufacturer's drive towards competitiveness and technological differentiation that drive their developments of technological capabilities. Technological uncertainty can thus arise from external and internal sources of the servitized manufacturer and requires adaptation in terms of their technological capabilities.

More interestingly, this research shows various patterns of interaction between these four uncertainty types. Table 4 lists seven interaction patterns observed in the presented cases. These patterns show interactions between two, three or four uncertainty types depending on the root cause (Simangunsong, Hendry, \& Stevenson, 2012) and level of extrapolation. Environmental uncertainty could directly influence all other three uncertainty types. Specifically regulation changes created environmental uncertainty in the presented cases which affected either organisational or relational uncertainty depending on the nature of the regulation. Similarly, environmental uncertainty could create technological uncertainty by creating a drive for technological developments either through pressures from competition or through customer needs. However, uncertainty could also originate as technological or organisational uncertainty - both on the provider and the customer side. If these uncertainty types remained unmanaged, they created knock-on effects to relational uncertainty, creating difficulties within the service 
Table 4

Summary of case findings on the interaction between uncertainty types.

\begin{tabular}{|c|c|c|}
\hline \multicolumn{2}{|c|}{$\begin{array}{l}\text { Observed patterns of interaction } \\
\text { between uncertainty types }\end{array}$} & \multirow{2}{*}{$\begin{array}{l}\text { Case examples } \\
\text { Case C: Changes to tendering process increases workload for } \\
\text { preparing competitive bid of PC }\end{array}$} \\
\hline 1) & Environmental uncertainty & \\
\hline 2) & Environmental uncertainty & $\begin{array}{l}\text { Case C: Changes to tendering process eliminates interaction between } \\
\text { potential providers and the customer as described by PC }\end{array}$ \\
\hline 3) & $\begin{array}{l}\downarrow \\
\text { Organironmental uncertainty } \\
\text { Relational uncertainty }\end{array}$ & $\begin{array}{l}\text { Case B: Changes in security policy affected CB's processes with } \\
\text { regard to required information to gain site access which in turn } \\
\text { affected PB who needed to provide the information in time to } \\
\text { perform the service activities } \\
\text { Case D: Growth of wind energy market and cuts in subsidies increase } \\
\text { customer's awareness of operations costs (CD) which in turn } \\
\text { encouraged CD to insource some of the service activities and control } \\
\text { provider actions; Market competition increases operational } \\
\text { pressures for PD to adapt strategy and a lack of doing so created } \\
\text { difficulties with CD by being overly protective of their activities }\end{array}$ \\
\hline 4) & Environmental uncertainty & $\begin{array}{l}\text { Case D: Increasing competition and technological changes in the } \\
\text { equipment leads PD to focus their business strategy }\end{array}$ \\
\hline 5) & $\begin{array}{l}\downarrow \\
\text { Technological uncertainty } \\
\text { Relational uncertainty }\end{array}$ & $\begin{array}{l}\text { Case C: Changing customer needs in terms of diagnosis quality and } \\
\text { speed gives incentives for technological developments in the } \\
\text { equipment which in turn led to high levels of specialisation of service } \\
\text { engineers with regard equipment type which in turn led to one point } \\
\text { of contact between provider and customer leading to long-term } \\
\text { personal relationships }\end{array}$ \\
\hline 6) & Technological uncertainty & $\begin{array}{l}\text { Case A: Technological developments on the equipment in terms of } \\
\text { new features increased difficulty for CA to do first-line service } \\
\text { activities in-house which in turn led to unnecessary calls for service } \\
\text { visits by CA }\end{array}$ \\
\hline 7) & Organisational uncertainty & $\begin{array}{l}\text { Case A: CA's lacking capabilities to process information internally led } \\
\text { to difficulties in arranging service visits for PA. } \\
\text { Case B: PB's lacking capabilities to process information internally led } \\
\text { to dissatisfied CB because relevant information was not provided } \\
\text { Case D: Internal misalignments of PD's departments led to } \\
\text { disagreements with CD }\end{array}$ \\
\hline
\end{tabular}

dyad. This research thus shows the interactions between uncertainty types analysing the root causes of observed uncertainty types.

The uncertainty-interaction patterns follow a causal chain from environmental uncertainty, technological uncertainty, organisational uncertainty, to relational uncertainty with possible direct and indirect knock-on effects between them. Fig. 1 summarises these interactions in a simplified scheme. The observations of a causal chain link to suggestions in the literature where knock-on effects were also observed as unidirectional (Kreye, 2017a). This research expands these descriptions by showing clear evidence for a causal chain of interactions between uncertainty types within servitization. This research shows that these causal chains can potentially be very long if manifestations of different uncertainty types are not managed and thus create knock-on effects in their own right. For example, if organisational uncertainty remains
Environmental uncertainty

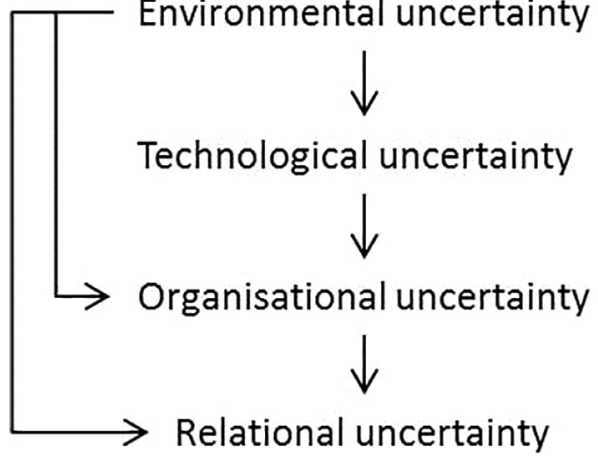

Fig. 1. Generalised scheme of interactions between uncertainty types. 
unmanaged, it creates a knock-on effect within the service dyad as relational uncertainty and thus affects the service partner. This research thus contributes to the discussion on uncertainty in servitization showing the interaction between uncertainty types.

\subsection{Managerial implications}

This research has important managerial implications in terms of uncertainty management. Specifically, we differentiate two managerial implications. First, this research enables the identification of root causes (Simangunsong et al., 2016) of perceived uncertainty that arise from dynamic interactions with other uncertainty types. Identifying these root causes enables managers to target them through suitable management activities aimed at utilising (Kreye, 2017b), increasing (Luotola et al., 2017), or reducing (Ulaga \& Kohli, 2018) this uncertainty within the service dyad. This enables managers to judge which management activities to engage in based on evaluating the purpose in terms of managing or coping with this uncertainty (Simangunsong et al., 2016). This research thus offers managers insights on the root causes of their perceived uncertainty within engineering services.

Second, this research enables managers to evaluate the relative effectiveness of different management activities targeted at different uncertainty types. Specifically, the effectiveness of specific management activities can be evaluated by considering the dynamic interaction between uncertainty types. Here, management activities, which are aimed at reducing one uncertainty type may have knock-on effects to other uncertainty types, may be more effective than management activities targeting one uncertainty type only. These considerations enable organisations to prioritise resources for management activities that are potentially most effective. This research thus enables managers to evaluate the relative effectiveness management activities targeted at uncertainty.

\subsection{Limitations and future work}

Due to the qualitative nature of the presented research, limitations apply which offer important routes for future work. Qualitative research has been connected to observer bias and subjectivity in data analysis (Yin, 2009). These limitations were mitigated by data triangulation where different data sources including different interviewees and other data sources were combined to improve reliability (Miles et al., 2014). Furthermore, the results are connected to contextual limitations within the studied industrial sectors. However, this research provided insights from multiple cases set in different industrial contexts within Europe. The multiple-case approach helped mitigate effects of specific industrial contexts (Beverland \& Lindgreen, 2010).

The presented work offers multiple areas for future research. First, including other industrial sectors would provide further breadth and generalisability. Specifically, sectors such as aerospace and defense have been described in their specific settings within the servitization literature and could thus offer further insights with respect to interactions between uncertainty types. Second, organisational uncertainty deserved further targeted research attention to identify a more nuanced characterisation within engineering services. Here, existing typologies such as the one used by Ulaga and Kohli (2018) could offer useful starting points in this context offering a process-focused categorisation of relevant internal uncertainty types. Third, providing quantitative research on the interactions between uncertainty types would further theory building in this area. Here, links between the existence of uncertainty types in terms of temporal manifestation or joint effects would benefit the literature on engineering services. Fourth, further work is needed to study the effect of the causal chain on service performance. Specifically, the length of the causal chain may have a detrimental effect on service quality. Further work is needed in this respect to identify the effect of uncertainty and lack of uncertainty management in this respect.

\section{References}

Baines, T., Lightfoot, H., Smart, P., \& Fletcher, S. (2013). Servitization of manufacture: Exploring the deployment and skills of people critical to the delivery of advanced services. Journal of Manufacturing Technology Management, 24(4), 637-646.

Beverland, M., \& Lindgreen, A. (2010). What makes a good case study? A positivist review of qualitative case research published in Industrial Marketing Management, 1971-2006. Industrial Marketing Management, 39(1), 56-63.

de Bruin, W. B., Fischbeck, P. S., Stiber, N. A., and Fischhoff, B., 2002. What number is 'fifty-fifty'?: Redistributing excessive $50 \%$ responses in elicited probabilities. Risk Analysis: An International Journal, 22 (4), 713-723.

Chao, X., Chen, H., \& Zheng, S. (2009). Dynamic capacity expansion for a service firm with capacity deterioration and supply uncertainty. Operations Research, 57(1), 82-93.

Dubois, A., \& Gadde, L. E. (2002). Systematic combining: An abductive approach to case research. Journal of Business Research, 55(7), 553-560.

Eisenhardt, K. M. (1989). Building theories from case study research. Academy of Management Review, 14(4), 532-550.

Eisenhardt, K. M., \& Graebner, M. E. (2007). Theory building from cases: Opportunities and challenges. Academy of Management Journal, 50(1), 25-32.

Eloranta, V., \& Turunen, T. (2016). Platforms in service-driven manufacturing: Leveraging complexity by connecting, sharing, and integrating. Industrial Marketing Management, 55, 178-186.

Forkmann, S., Ramos, C., Henneberg, S. C., \& Naudé, P. (2017). Understanding the service infusion process as a business model reconfiguration. Industrial Marketing Management, 60, 151-166.

Galbraith, J. R. (1974). Organization design: An information processing view. Interfaces, 4(3), 28-36.

Galbraith, J. R. (2002). Organizing to deliver solutions. Organizational Dynamics, 31(2), 194-207.

Hakanen, T., Helander, N., \& Valkokari, K. (2017). Servitization in global business-tobusiness distribution: The central activities of manufacturers. Industrial Marketing Management, 63, 167-178.

Hawkins, T. G., Gravier, M. J., Berkowitz, D., \& Muir, W. A. (2015). Improving services supply management in the defense sector: How the procurement process affects B2B service quality. Journal of Purchasing and Supply Management, 21(2), 81-94.

Hoskisson, R. E., Eden, L., Lau, C. M., \& Wright, M. (2000). Strategy in emerging economies. Academy of Management Journal, 43(3), 249-267.

Hypko, P., Tilebein, M., \& Gleich, R. (2010). Benefits and uncertainties of performancebased contracting in manufacturing industries. Journal of Service Management, 21(4), 460-489.

Kastalli, I. V., \& Van Looy, B. (2013). Servitization: Disentangling the impact of service business model innovation on manufacturing firm performance. Journal of Operations Management, 31(4), 169-180.

Kowalkowski, C., Gebauer, H., Kamp, B., \& Parry, G. (2017). Servitization and deservitization: Overview, concepts, and definitions. Industrial Marketing Management, 60 4-10.

Kowalkowski, C., Windahl, C., Kindström, D., \& Gebauer, H. (2015). What service transition? Rethinking established assumptions about manufacturers' service-led growth strategies. Industrial Marketing Management, 45(February), 59-69.

Kreye, M. E. (2017a). Can you put too much on your plate? Uncertainty exposure in servitized triads. International Journal of Operations \& Production Management, 37(12), 1722-1740.

Kreye, M. E. (2017b). Relational uncertainty in service dyads. International Journal of Operations \& Production Management, 37(3), 363-381.

Kreye, M. E., Goh, Y. M., Newnes, L. B., \& Goodwin, P. (2012). Approaches of displaying information to assist decisions under uncertainty. Omega - International Journal of Management Science, 40(6), 682-692.

Kreye, M. E., Newnes, L. B., \& Goh, Y. M. (2013). Information availability at the competitive bidding stage for service. Journal of Manufacturing Technology Management, 24(7), 976-997.

Kreye, M. E., Newnes, L. B., \& Goh, Y. M. (2014). Uncertainty in competitive bidding - A framework for product - Service systems. Production Planning \& Control, 25(6), $462-477$.

Kreye, M. E., Roehrich, J. K., \& Lewis, M. A. (2015). Servitising manufacturers: The im pact of service complexity and contractual and relational capabilities. Production Planning \& Control, 26(14), 1233-1246.

Kuijken, B., Gemser, G., \& Wijnberg, N. M. (2017). Effective product-service systems: A value-based framework. Industrial Marketing Management, 60, 33-41.

Kumar, N., \& Yakhlef, A. (2016). Managing business-to-business relationships under conditions of employee attrition: A transparency approach. Industrial Marketing Management, 56, 143-155.

Lewis, M. A. (2003). Cause, consequence and control: Towards a theoretical and practical model of operational risk. Journal of Operations Management, 21(2), 205-224.

Luoto, S., Brax, S. A., \& Kohtamäki, M. (2017). Critical meta-analysis of servitization research: Constructing a model-narrative to reveal paradigmatic assumptions. Industrial Marketing Management, 60, 89-100.

Luotola, H., Hellström, M., Gustafsson, M., \& Perminova-Harikoski, O. (2017). Embracing uncertainty in value-based selling by means of design thinking. Industrial Marketing Management, 65(June), 59-75.

Melander, L., \& Lakemond, N. (2015). Governance of supplier collaboration in technologically uncertain NPD projects. Industrial Marketing Management, 49, 116-127.

Milliken, F. J. (1987). Three types of perceived uncertainty about the environment: State, 
effect, and response uncertainty. Academy of Management Review, 12(1), 133-143.

Miles, M. B., Huberman, A. M., \& Saldaña, J. (2014). Qualitative data analysis: A methods sourcebook (3rd ed.). Thousand Oaks, CA, USA: Sage Publications, Inc.

Nordin, F., Kindström, D., Kowalkowski, C., \& Rehme, J. (2011). The risks of providing services: Differential risk effects of the service-development strategies of customisation, bundling, and range. Journal of Service Management, 22(3), 390-408.

Nullmeier, F. M. E., Wynstra, F., \& van Raaij, E. M. (2016). Outcome attributability in performance-based contracting: Roles and activities of the buying organization. Industrial Marketing Management, 59, 25-36.

O'Connor, G. C., \& Rice, M. P. (2013). A comprehensive model of uncertainty associated with radical innovation. Journal of Product Innovation Management, 30(1), 2-18.

Pince, C., Frenk, J., \& Dekker, R. (2015). The role of contract expirations in service parts management. Production and Operations Management, 24(10), 1580-1597.

Pearson, C. M., \& Clair, J. A. (1998). Reframing crisis management. The Academy of Management Review, 23(1), 59-76.

Pereira, V. R. and Carvalho, M. M. de, 2011. Services in Manufacturing - A study of product orientation in product- service systems. EurOMA.

Piekkari, R., Plakoyiannaki, E., \& Welch, C. (2010). 'Good' case research in industrial marketing: Insights from research practice. Industrial Marketing Management, 39(1), 109-117.

Reim, W., Parida, V., \& Sjödin, D. R. (2016). Risk management for product-service system operation. International Journal of Operations \& Production Management, 36(6), $665-686$.

Richey, R. G., Musgrove, C. F., Gillison, S. T., \& Gabler, C. B. (2014). The effects of environmental focus and program timing on green marketing performance and the moderating role of resource commitment. Industrial Marketing Management, 43(7), 1246-1257.

Sampson, S. E., \& Spring, M. (2012). Customer roles in service supply chains and opportunities for innovation. Journal of Supply Chain Management, 48(4), 30-50.

Sanchez Rodrigues, V. A., Potter, A. T., \& Naim, M. M. (2010). The impact of logistics uncertainty on sustainable transport operations. International Journal of Physical Distribution \& Logistics Management, 40(1/2), 61-83.

Siggelkow, N. (2007). Persuasion with case studies. Academy of Management Journal, 50(1), 20-24.

Simangunsong, E., Hendry, L. C., \& Stevenson, M. (2012). Supply-chain uncertainty: A review and theoretical foundation for future research. International Journal of
Production Research, 50(16), 4493-4523.

Simangunsong, E., Hendry, L. C., \& Stevenson, M. (2016). Managing supply chain uncertainty with emerging ethical issues. International Journal of Operations \& Production Management, 36(10), 1272-1307.

Selviaridis, K. (2016). Contract functions in service exchange governance: Evidence from logistics outsourcing. Production Planning and Control, 27(16), 1373-1388.

Ulaga, W., \& Eggert, A. (2006). Relationship value and relationship quality: Broadening the nomological network of business-to-business relationships. European Journal of Marketing, 40(3/4), 311-327.

Ulaga, W., \& Kohli, A. K. (2018). The role of a solutions salesperson: Reducing uncertainty and fostering adaptiveness. Industrial Marketing Management, 69(February), 161-168 (November), $0-1$.

Vandermerwe, S., \& Rada, J. (1988). Servitization of business: Adding value by adding services. European Management Journal, 6(4), 314-324.

Vargo, S. L., \& Lusch, R. F. (2004). Evolving to a new dominant logic for marketing. Journal of Marketing, 68(1), 1-17.

van der Vorst, J., \& Beulens, A. (2002). Identifying sources of uncertainty to generate supply chain redesign strategies. International Journal of Physical Distribution \& Logistics Management, 34(1), 6-24.

Valtakoski, A. (2017). Explaining servitization failure and deservitization: A knowledgebased perspective. Industrial Marketing Management, 60, 138-150.

Yin, R. K. (2009). Case study research: Design and methods. Los Angeles, CA, USA: SAGE Publications.

Yang, M., \& Gabrielsson, P. (2017). Entrepreneurial marketing of international high-tech business-to-business new ventures: A decision-making process perspective. Industrial Marketing Management, 64, 147-160.

Yang, W., Gao, Y., Li, Y., Shen, H., \& Zheng, S. (2017). Different roles of control mechanisms in buyer-supplier conflict: An empirical study from China. Industrial Marketing Management, 65(December 2015), 144-156.

Zhang, W., \& Banerji, S. (2017). Challenges of servitization: A systematic literature review. Industrial Marketing Management, 65(June), 217-227.

Zink, K. J., Baudach, T., and Kramp, M., 2010. Development of hybrid solutions - a challenge for organizations in a competitive environment. In: Salvendy, G. and Karwowski, W., eds. Intoduction to service engineering. Hoboken, NJ, USA: Wiley \& Sons Ltd. Publications, 73-99. 